\title{
What Keeps Online Customers Repurchasing through the Internet?
}

\author{
KANOKWAN ATCHARIYACHANVANICH, HITOSHI OKADA and \\ NOBORU SONEHARA
}

\begin{abstract}
Factors affecting the intention of purchasing online have been investigated for many years. On the other hand, the question of what keeps online customers repurchasing through the Internet has rarely been examined. By expanding the existing customer satisfaction/continuance model based on the expectation-confirmation model, this study aims to provide a theoretical model that can support technical, business, and consumer issues involved in online repurchasing. The results of an online questionnaire of 1,215 Japanese online customers pointed out that not only basic factors of confirmation, satisfaction, perceived usefulness, and perceived incentives, but a new factor, customer loyalty, are factors significantly influencing the online customers' intention to repeat purchase through the Internet. This study sheds light on the development of online incentive technology and the means of enhancing customer loyalty to promote online repurchasing.
\end{abstract}

Categories and Subject Descriptors: K.4.4 [Computers and Society]: Electronic Commerce General Terms: Online repurchasing, Intention to repurchase, Satisfaction, Customer loyalty, Incentives Additional Key Words and Phrases: Perceived usefulness, expectation-confirmation model

\section{INTRODUCTION}

The Internet has become a borderless medium that is rapidly extending its coverage to sectors ranging from education to business. Electronic commerce (EC) is at the core of this expansion, and its scale of growth rate varies among countries. In Japan, the growth in EC spending was forecasted to decrease from $26.9 \%$ in 2004 to $21.06 \%$ in 2007 [International Data Corporation, 2004]. This decrease rate can be explained by looking at the impact of customers' behavior on EC. There are plenty of studies on customer behavior that investigate the factors influencing purchases through the Internet. However, the factors affecting repeat purchasing through Internet shopping are also important.

Since keeping the customer repurchasing on product/service is essential to maintain the profitability of any business, the continuance of purchasing through the Internet is

This research is a part of the Digital Eizou Common Specification Development Project (DECSDP) and was supported by the Science and Technology Promotion Adjustment Budget of the Ministry of Education, Culture, Sports, Science and Technology, Japan.

Authors' addresses: Department of Informatics, The Graduate University for Advanced Studies, Shonan Village, Hayama, Kanagawa, 240-0193 Japan, National Institute of Informatics, 2-1-2 Hitotsubashi, Chiyoda-ku, Tokyo, 101-8430 Japan, \{kanokwan\}@grad.nii.ac.jp

Permission to make digital/hard copy of part of this work for personal or classroom use is granted without fee provided that the copies are not made or distributed for profit or commercial advantage, the copyright notice, the title of the publication, and its date of appear, and notice is given that copying is by permission of the ACM, Inc. To copy otherwise, to republish, to post on servers, or to redistribute to lists, requires prior specific permission and/or a fee.

(c) $2006 \mathrm{ACM} / 2006 /-0047 \$ 5.00$ 
vital to business. Despite this need to succeed in business [Goodwin and Ball 2003], the factors affecting the repeat purchasing on the Internet have rarely been explored. This paper is one of the first studies to examine the key factors underlying customers' intention to repurchase through the Internet, and it is based on a synthesis of expectationconfirmation theory (ECT), theory of acceptance model (TAM), and several other ideas presented in the literature [Bhattacherjee 2001a, 2001b; Kim et al. 2000; Gefen 2002]. The hypothesized research model was tested using an online questionnaire of online customers who purchased products/services through Internet shopping. It helps to clarify the repurchasing behavior of online customers.

\section{THEORETICAL BACKGROUND}

The theoretical constructs pertinent to this study are the intention to repurchase and behavior prediction. ECT was designed to explain the determinants of intention to repurchase for a wide range of products and service continuance contexts, including automobile repurchases, camcorder repurchases, institutional repurchases of photographic products, restaurant services, and online brokerage services [Bhattacherjee 2001a, 2001b; Kim et al. 2003]. Regarding the underlying logic of the ECT model as described by Oliver [1980] and Bhattacherjee [2001a, 2001b], the model posits that confirmation and satisfaction are the primary determinants of the intention to repurchase. Confirmation is the assessment of customers' perceived performance versus their original expectation, and it determines the extent to which their expectation is confirmed. In turn, customer satisfaction is formed based on the customers' confirmation level and the expectation on which that confirmation is based. The model hypothesizes that the intention to repurchase is determined by satisfaction, which is in turn influenced by confirmation. Finally, the intention to repurchase is formed by satisfied customers. Satisfied customers continue purchasing through the Internet, whereas dissatisfied customers discontinue subsequent purchases.

\subsection{Existing model}

Many studies on customer behavior, in particular, customer satisfaction and intention to repurchase, have applied expectation-confirmation theory in the EC context. One of the outstanding studies examined the antecedents of customers' intention to continue to use an online brokerage, which is a kind of EC service [Bhattacherjee 2001b]. Its model 
combines the underlying factor of TAM, which is perceived usefulness. The study confirmed the research hypotheses that perceived usefulness is directly influenced by confirmation and that it directly affects the intention to continue using an EC service. Only loyalty incentives do not have any significant effect on intention to continue, yet their interaction with perceived usefulness is significant. The strength of this study is that it combines TAM's perceived usefulness variables and economics' loyalty incentives with ECT. In addition, it has been proved in the domain of EC service that other services, such as Internet shopping, are interesting topics for further investigation. Although loyalty incentives are determinants of the intention to continue receiving service, they pertain to loyalty only in terms of the tangible benefit that the customers receive if they continue using the EC service.

\subsection{Customer Loyalty as a New Factor}

Customer loyalty is defined as "a deeply held commitment to rebuy or repatronize a preferred product or service consistently in the future, despite situational influences and marketing efforts having the potential to cause switching behavior" [Oliver 1996]. Customer loyalty is a recurring research issue for both marketing and IT-related businesses [Chiou 2004; Chung and Lee 2003; Gefen 2002; Goodwin and Ball 2003; Homburg and Giering 2001; Lee et al. 2000; Oliver 1996, 1999]. As Internet shopping is an emergence of marketing channels and IT, customer loyalty is crucial to its success. It is an important source of success and growth of customer-centric business [Crosby and Johnson 2005] because it drives the growth of revenue and affects profit [Crosby and Johnson 2005; Oliver 1996, 1999]. If no customer is willing to revisit an Internet shop, its business value becomes zero regardless of its technical or managerial assets [Lee et al. 2000]. Customer loyalty is vital because the value of a shop and the growth of its business are mainly determined by the number of loyal customers in the context of the EC [Lee et al. 2000] and the number of retained customers in the context of any business [Crosby and Johnson 2005]. Moreover, empirical studies showing the relationship between customer satisfaction and loyalty in online and offline environments indicate that they have a mutual relationship such that each positively reinforces the other, and this relationship is further strengthened online [Shankar et al. 2003]. Online customers must be satisfied before they will return for more purchases at a site. Therefore, this adds a new factor, customer loyalty, to the research model of this study. 


\section{RESEARCH MODEL AND HYPOTHESES}

The synthesis of the strength of the base model and the potential customer loyalty factor composes the research model of this study. The behavior relationship model can be represented and evaluated in the form of a factor network that consists of constructs and links between the constructs. The hypotheses that we investigated are as follows.

H1: A customer's satisfaction with Internet shopping positively affects his or her intention to repurchase through Internet shopping $(S \rightarrow R)$.

H2: A customer's confirmation level positively affects his or her satisfaction with Internet shopping $(\mathrm{C} \rightarrow \mathrm{S})$.

H3: A customer's perceived usefulness of Internet shopping positively affects his or her intention to repurchase through Internet shopping $(\mathrm{PU} \rightarrow \mathrm{R})$.

H4: A customer's confirmation level positively affects his or her perceived usefulness of Internet shopping $(\mathrm{C} \rightarrow \mathrm{PU})$.

H5: A customer's perceived incentives positively affect his or her intention to repurchase through Internet shopping $(I \rightarrow R)$.

H 6: A customer's loyalty positively affects his or her intention to repurchase through the Internet shopping $(\mathrm{L} \rightarrow \mathrm{R})$.

H7: A customer's satisfaction with Internet shopping positively affects his or her customer loyalty $(\mathrm{S} \rightarrow \mathrm{L})$.

\section{RESEARCH METHODOLOGY}

\subsection{Measurement Development}

Six constructs, including repurchase intention, satisfaction, confirmation, perceived usefulness, perceived incentives, and customer loyalty, were measured using multi-item scales. Each construct contains several items measured by the fully anchored, 5-point Likert scale ranging from (1) "strongly agree" to (5) "strongly disagree". The items were generated from previous research projects and were modified to fit the context of Internet shopping when necessary. As the survey was conducted in Japan, a Japanese version of the questionnaire was administrated. The questionnaire, originally written in English, was translated into Japanese by bilingual people whose native language is Japanese and whose background is IT-oriented. The questionnaire was then translated back into English by other bilingual people whose native language is English and whose 
background is IT-oriented. The English version was then compared, and no item was found to pertain to a specific cultural context in terms of language or to a specific ITrelated context in terms of background translation. Each construct included at least three items to assure adequate reliability, as recommended by Nunnally [1978].

\subsection{Data Collection}

An online survey targeted at potential online users who have had the experience of purchasing a product or service while Internet shopping was utilized to collect data. The online survey was selected as a tool to gather data because of its advantages over e-mail surveys, i.e., better display, more interactive, easier to fill in, and improved data quality [Ilieva et al. 2002]. All questions were posted on a reliable website with four million registered users operated by GOO Company, www.goo.ne.jp in Japan. The period of the questionnaire ran from July 21 to 25,2006 . After the initial screening for reliability and validity, 1,215 responses were found to be complete and usable.

\section{DATA ANALYSIS}

The data analysis employed a two-step approach [Anderson and Gerbing 1988] using a statistical program, SPSS, and a covariance-based program, AMOS. In the first step, the measurement model was examined for instrument validity and refinement by using confirmatory factor analysis (CFA). The second step involved confirming the relationships and testing the hypotheses of the research model by using the structural equation modeling (SEM) technique.

\subsection{Measurement Model}

CFA was performed to validate the posited relations of the observed variables and the underlying constructs in the measurement model. An exploratory factor analysis (EFA) was not employed because no prior specification of the number of factors is exclusively exploratory [Anderson and Gerbing 1988]. Hence, in this study, the CFA is more appropriate than EFA. All items are indicated in Appendix A, and the results of the analysis, along with descriptive statistics (item means and standard deviation), are presented in Table I.

The construct validity for each construct was assessed by examining the standardized factor loadings obtained from the measurement model. After performing the initial CFA 
analysis, 20 items out of the 22 items for the six constructs conformed to an accepted minimum factor loading of 0.60 [Nunnally 1978]. Two items (in the perceived incentive and customer loyalty scales) had factor loadings in the low range of 0.1-0.5. These items were removed from subsequent analyses. Their removal implies that I3 (Internet shopping generally does not give me any incentives for me to continue shopping on it) was less related to other items in terms of the perceived incentive factor. In addition, L4 (I am inclined to shop more via the Internet) was also weakly correlated with other items in the customer loyalty factor.

Table I. Factor Loadings and Factor Reliabilities

\begin{tabular}{|c|c|c|c|c|c|}
\hline Construct & Item & Mean & S.D. & $\mathrm{CR}^{*}$ & Standardized factor loadings ${ }^{*}$ \\
\hline \multirow[t]{3}{*}{ Repurchase } & $\mathrm{R} 1$ & 2.11 & 0.70 & $\begin{array}{l}0.800 \\
(0.872)\end{array}$ & $0.607^{\mathrm{a}, \dagger}$ \\
\hline & $\mathrm{R} 2$ & 2.95 & 0.91 & & $0.852^{\mathrm{a}}\left(0.868^{\mathrm{a}}\right)$ \\
\hline & R3 & 3.01 & 0.99 & & $0.864^{\mathrm{a}}\left(0.891^{\mathrm{a}}\right)$ \\
\hline \multirow[t]{3}{*}{ Satisfaction } & S1 & 2.76 & 0.93 & $\begin{array}{l}0.774 \\
(0.815)\end{array}$ & $0.640^{\mathrm{a}, \dagger}$ \\
\hline & $\mathrm{S} 2$ & 2.33 & 0.74 & & $0.826^{\mathrm{a}}\left(0.835^{\mathrm{a}}\right)$ \\
\hline & S3 & 2.38 & 0.70 & & $0.787^{\mathrm{a}}\left(0.808^{\mathrm{a}}\right)$ \\
\hline \multirow[t]{3}{*}{ Confirmation } & $\mathrm{C} 1$ & 2.31 & 0.69 & 0.717 & $0.619^{\mathrm{a}}\left(0.618^{\mathrm{a}}\right)$ \\
\hline & $\mathrm{C} 2$ & 2.78 & 0.72 & & $0.573^{\mathrm{a}}\left(0.577^{\mathrm{a}}\right)$ \\
\hline & $\mathrm{C} 3$ & 2.53 & 0.71 & & $0.734^{\mathrm{a}}\left(0.746^{\mathrm{a}}\right)$ \\
\hline \multirow[t]{5}{*}{ Perceived Usefulness } & PU1 & 2.01 & 0.82 & 0.883 & $0.735^{\mathrm{a}}\left(0.735^{\mathrm{a}}\right)$ \\
\hline & PU2 & 2.28 & 0.91 & & $0.748^{\mathrm{a}}\left(0.749^{\mathrm{a}}\right)$ \\
\hline & PU3 & 1.96 & 0.82 & & $0.750^{\mathrm{a}}\left(0.751^{\mathrm{a}}\right)$ \\
\hline & PU4 & 1.99 & 0.73 & & $0.814^{\mathrm{a}}\left(0.814^{\mathrm{a}}\right)$ \\
\hline & PU5 & 1.99 & 0.76 & & $0.852^{\mathrm{a}}\left(0.851^{\mathrm{a}}\right)$ \\
\hline \multirow[t]{4}{*}{ Perceived Incentive } & I1 & 2.17 & 0.80 & $\begin{array}{l}0.556 \\
(0.785) \\
\end{array}$ & $0.661^{\mathrm{a}}\left(0.659^{\mathrm{a}}\right)$ \\
\hline & $\mathrm{I} 2$ & 2.43 & 1.00 & & $0.894^{\mathrm{a}}\left(0.894^{\mathrm{a}}\right)$ \\
\hline & $\mathrm{I} 3$ & 3.46 & 0.94 & & $0.125^{\mathrm{a}, \grave{ }}$ \\
\hline & $\mathrm{I} 4$ & 2.81 & 0.96 & & $0.696^{\mathrm{a}}\left(0.700^{\mathrm{a}}\right)$ \\
\hline \multirow[t]{4}{*}{ Customer Loyalty } & L1 & 2.45 & 0.69 & $\begin{array}{l}0.745 \\
(0.816)\end{array}$ & $0.783^{a}\left(0.880^{a}\right)$ \\
\hline & $\mathrm{L} 2$ & 2.81 & 0.81 & & $0.773^{\mathrm{a}}\left(0.795^{\mathrm{a}}\right)$ \\
\hline & L3 & 2.95 & 0.93 & & $0.736^{\mathrm{a}, \dagger}$ \\
\hline & L4 & 3.20 & 1.00 & & $0.412^{\mathrm{a}, \dagger}$ \\
\hline
\end{tabular}

${ }^{\mathrm{a}}$ Significant at $p<0.001,{ }^{\mathrm{ns}}$ Non-significant at $p=0.05$

* Parentheses indicate parameters after scale revision.

${ }^{\dagger}$ These items were removed from the final model.

In addition to construct validity, the internal consistency of the measurement model was assessed by computing the composite reliability (CR). After dropping two unqualified items in the construct validity step, all six constructs had high composite reliability ranging from 0.71 to 0.88 compared with the acceptance level of 0.60 [Bagozzi and Yi 1988]. However, the composite reliability test recommended that some items be 
removed to increase the composite reliable norm. The composite reliabilities of three factors (repurchase, satisfaction, and customer loyalty) increased after removing R1, S1 and L3. This indicates that the data has high internal reliability. Confirmation and perceived usefulness factors did not need any item to be removed from the model because their composite reliabilities met the highest norm.

\subsection{Structural Model}

The initial test of the structural model estimated the goodness-of-fit of initial and revised models so that the hypothesized model would be a good representation of the structures underlying the observed data. The chi-square of the revised model is calculated to be $588.10(p=0.0)$ with 111 degrees of freedom. After revising the initial model, the root mean square error of approximation (RMSEA) is 0.060 , which indicates a good fit and reasonable errors of approximation in the population and is lower than the recommended limit of 0.08 [MacCallum et al. 1996]. The root mean square residual (RMR) is 0.031, which is lower than the accepted limit of 0.05 recommended by Byrne [2001]. The goodness of fit index (GFI) of 0.95, the normed fit index (NFI) of 0.95, and the comparative fit index (CFI) of 0.96 meet the recommended levels of $0.90,0.95$, and 0.90 , respectively [Byrne 2001].

\subsection{Hypotheses Testing}

This step examined the path significance of each relation in our research model and variance explained ( $R^{2}$ value) of each path. Figure 1 shows the results of the structural paths of the research model. The estimated path effects (standardized) are presented along with the $t$-values. All path coefficients are significant at $p=0.001$, which indicates strong support for all the hypothesized relationships. These results represent yet another confirmation of the appropriateness of the ECT for explaining voluntary individual behavior in general and are a strong indication of its applicability to the intention to repurchase in Internet shopping in particular. They also provide strong support for the new path added to the ECT representing the effect of customer loyalty.

Intention to repurchase was predicted by satisfaction $(\beta=0.27)$, perceived usefulness ( $\beta=0.22)$, customer loyalty $(\beta=0.19)$, and perceived incentives $(\beta=0.14)$, which accounted for $46 \%$ of the repurchase variance. Satisfaction had the strongest effect, emphasizing the important role of an individual's intention to repurchase through the 
Internet. Satisfaction, in turn, was predicted by confirmation $(\beta=0.96)$, which accounted for $92 \%$ of the satisfaction variance. Confirmation also had a strong effect on perceived usefulness, with a path coefficient of 0.71 . Customer loyalty was predicted by satisfaction ( $\beta=0.79$ ), which accounted for $62 \%$ of the customer loyalty variance.

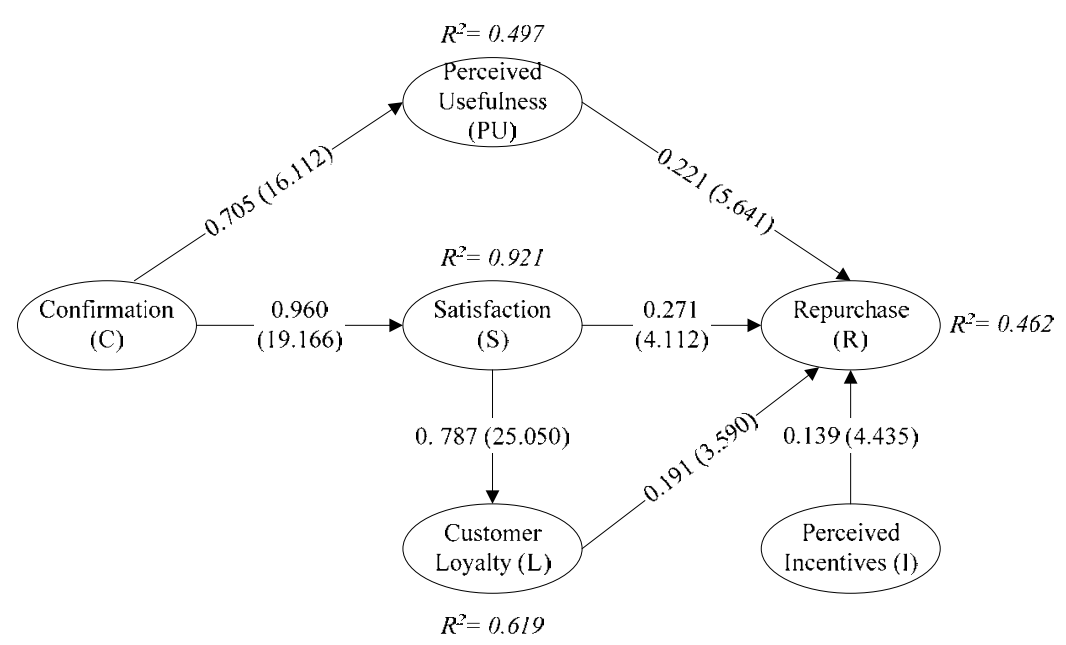

Path significance at $p<0.001$. Values in parentheses are $t$-values.

Fig. 1. Final Model of Repurchasing Factors of Internet Shopping

\section{DISCUSSION AND CONCLUSION}

All five factors, i.e., satisfaction, confirmation, perceived usefulness, customer loyalty and perceived incentives, keep the online customer repurchasing through the Internet. The results indicated perceived usefulness, the underlying factor of TAM, was a determinant of repurchase intention. This implies that TAM can be combined with ECT to develop the model of repurchasing behavior. In addition, the findings support the existing theoretical links of ECT as well as the customer loyalty factor that we newly hypothesized in this study. Specifically, we found that perceived incentives had a significant effect on the intention to repurchase, which is contrast to the finding of Bhattacherjee [2001b]. Therefore, it deserves to study what kind of incentives and which incentive tools are useful for promoting online repurchasing. Our study shows that customer loyalty is nearly as important as perceived usefulness in influencing the repurchase intention. This implies that not only perceived usefulness but also customer 
loyalty are strong indicators of customers' intention to repurchase through the Internet. Therefore, customer loyalty is one of the factors affecting online repurchasing. It would be interesting to determine if customer loyalty by itself has any effect on the intention to repurchase.

Moreover, as our model of repurchasing factors of Internet shopping has been validated and it well explains the repurchasing behavior of Japanese online customers, it should be validated with respondents from different nationalities such as Chinese, and Americans. For instance, regarding Whitcomb et al. [1998]'study on business ethical values in China and the U.S., Chinese are sometimes more motivated by profit than American are. This can be hypothesized that the perceived incentive of Chinese may be higher than that of American. Moreover, since our respondents are Japanese, whose consumption behavior is notably different from other societies [Synodinos 2001], a comparative study on online repurchasing factors in other countries is a potential way of extending the current study. The differences between online customer nationalities regarding their perceptions about repurchasing through the Internet will yield insights that can help Internet shops better retain customers in different world market segments.

\section{REFERENCES}

ANDERSON, J. C., AND GERBING, D. W. 1988. Structural equation modeling in practice: A review and recommended two-step approach. Psychological Bulletin 103, 3, 411-423.

BAGOZZI, R. AND YI, T. 1988. On the evaluation of structural equation models. Journal of the Academy of Marketing Science 16, 1, 74-94.

BHATTACHERJEE, A. 2001a. Understanding information systems continuance: An expectation-confirmation model. MIS Quarterly 25, 3, 351-370.

BHATTACHERJEE, A. 2001b. An empirical analysis of the antecedents of electronic commerce service continuance. Decision Support Systems 32, 201-214.

BYRNE, M. B. 2001. Structural Equation Modeling with AMOS: Basic concepts, Applications, and Programming. Lawrence Erlbaum Associates Inc., New Jersey.

CHEN, L., GILLENSON, M. L., and SHERRELL, D. L. 2004. Consumer acceptance of virtual stores: A theoretical model and critical success factors for virtual stores. ACM SIGMIS Database 35, 2, 8-31.

CHIOU, J.-S. 2004. The antecedents of consumers' loyalty toward Internet Service Providers. Information \& Management 41, 685-695.

CHUNG, I. K., AND LEE, M. M. 2003. A study of influencing factors for repurchase intention in Internet shopping malls. In Proceeding of the International Parallel and Distributed Processing Symposium, Nice, France, 243a.

CROSBY, L. A. AND JOHNSON, S. L. 2005. Growing up. Marketing Management 14, 2, 12-13.

GEFEN, D. 2002. Customer loyalty in E-commerce. Journal of the Association for Information Systems 3, $27-$ 51.

DAVIS, F. D. 1989. Perceived usefulness, perceived ease of use, and user acceptance of information technology. MIS Quarterly 13, 3, 319-340.

GOODWIN, R. AND BALL, B. 2003. What marketing wants the CEO to know. Marketing Management 12, 5, 18-23.

HOMBURG, C. AND GIERING, A. 2001. Personal characteristics as moderators of the relationship between customer satisfaction and loyalty. Psychology and Marketing 18, 1, 43-66.

ILIEVA, J., BARON, S. AND HEALEY, N. M. 2002. Online surveys in marketing research: pros and cons. International Journal of Market Research 44, 3, 361-376. 
INTERNATIONAL DATA CORPORATION 2004. Internet Commerce Market Model, Version 9.1. IDC, Framingham, MA.

JONES, T. O., and SASSER, W. E. 1995. Why satisfied customers defect. Harvard Business Review, 88-99. KIM, D. J, CHO, B., AND RAO, H. R. 2000. Effects of consumer lifestyles on purchasing behavior on the Internet: a conceptual framework and empirical validation. In Proceedings of the 21 st International Conference on Information Systems, Australia, $688-695$.

KIM, D. J, FERRIN, D. L., AND RAO, H. R. 2003. A Study of the effect of consumer trust on consumer expectations and satisfaction: the Korean experience. In Proceedings of the 5th International Conference on Electronic Commerce, Pittsburgh, Pennsylvania, 310-315.

LEE, J., KIM, J., AND MOON, J. Y. 2000. What makes Internet users visit cyber stores again? Key design factors for customer loyalty. CHI Letters 2, 1, 305-312.

MACCALLUM, R. C., BROWNE, M. W., AND SUGAWARA, H. M. 1996. Power analysis and determination of sample size for covariance structure modeling. Psychological Methods 1, 2, 130-149.

NUNNALLY, J. C. 1978. Psychometric Theory. McGraw-Hill, New York.

OLIVER, R. L. 1980. A cognitive model for the antecedents and consequences of satisfaction. Journal of Marketing Research 17, 4, 460-469.

OLIVER, R. L. 1996. Satisfaction: A Behavioral Perspective on the Consumer. McGraw-Hill, New York.

OLIVER, R. L. 1999. Whence consumer loyalty?. Journal of Marketing 63, 33-44.

SHANKAR, V., SMITH, A. K. AND RANGASWAMY, A. 2003. Customer satisfaction and loyalty in online and offline environments. International Journal of Research in Marketing 20, 153-175.

SYNODINOS, N. E. 2001. Understanding Japanese consumers: some important underlying factors. Japanese Psychological Research 43, 4, 235-248.

WHITCOMB, L. L., ERDENER, C. B., AND LI, C. 1998. Business Ethical Values in China and the U.S.

Journal of Business Ethics 17, 839-852. 
What Keeps Online Customers Repurchasing through the Internet? · 57

APPENDIX A

\begin{tabular}{|c|c|c|}
\hline Code & Item & Source \\
\hline \multicolumn{3}{|c|}{ Repurchase intention } \\
\hline $\mathrm{R} 1$ & $\begin{array}{l}\text { I want to continue purchasing through the Internet rather than } \\
\text { discontinue its use. }\end{array}$ & \multirow{3}{*}{$\begin{array}{l}\text { Bhattacherjee } \\
\text { [2001b] }\end{array}$} \\
\hline R2 & $\begin{array}{l}\text { My intentions are to continue purchasing through the Internet } \\
\text { rather than any alternative means (traditional store). }\end{array}$ & \\
\hline R3 & $\begin{array}{l}\text { Internet shopping will become my first choice when I buy a } \\
\text { product. }\end{array}$ & \\
\hline \multicolumn{3}{|c|}{ Satisfaction } \\
\hline S1 & I am delighted with my experience of Internet shopping. & \multirow{3}{*}{$\begin{array}{l}\text { Bhattacherjee } \\
{[2001 \mathrm{~b}]}\end{array}$} \\
\hline S2 & $\begin{array}{l}\text { I am very happy to purchase the product from the Internet } \\
\text { shopping. }\end{array}$ & \\
\hline S3 & I am satisfied with my decision to purchase through the Internet. & \\
\hline \multicolumn{3}{|c|}{ Confirmation } \\
\hline $\mathrm{C} 1$ & $\begin{array}{l}\text { Internet shopping gives me all the information needed to place } \\
\text { and execute the purchase. }\end{array}$ & \multirow{3}{*}{$\begin{array}{l}\text { Bhattacherjee } \\
\text { [2001a; 2001b] }\end{array}$} \\
\hline $\mathrm{C} 2$ & $\begin{array}{l}\text { After-sale services provided by Internet shopping meet my } \\
\text { expectations. }\end{array}$ & \\
\hline $\mathrm{C} 3$ & $\begin{array}{l}\text { Overall, most of my expectations from using Internet shopping } \\
\text { were confirmed. }\end{array}$ & \\
\hline \multicolumn{3}{|c|}{ Perceived usefulness } \\
\hline PU1 & $\begin{array}{l}\text { Using Internet shopping would improve my performance in } \\
\text { shopping or information seeking (e.g. save time or money). }\end{array}$ & \multirow{5}{*}{$\begin{array}{l}\text { David [1989] } \\
\text { and Chen et al. } \\
\quad[2004]\end{array}$} \\
\hline PU2 & $\begin{array}{l}\text { Using Internet shopping would increase my productivity in } \\
\text { shopping or information seeking (e.g. make purchase decisions or } \\
\text { find product information within the shortest time frame). }\end{array}$ & \\
\hline PU3 & $\begin{array}{l}\text { Using Internet shopping would enhance my effectiveness in } \\
\text { shopping or information seeking (e.g. get the best deal or find the } \\
\text { most information about a product). }\end{array}$ & \\
\hline PU4 & $\begin{array}{l}\text { Using Internet shopping would make it easier for me to shop or } \\
\text { find information. }\end{array}$ & \\
\hline PU5 & $\begin{array}{l}\text { I find Internet shopping very useful for shopping or information } \\
\text { seeking. }\end{array}$ & \\
\hline \multicolumn{3}{|c|}{ Perceived incentives } \\
\hline I1 & $\begin{array}{l}\text { Internet shopping offers incentives for its continued use such as } \\
\text { points. }\end{array}$ & \multirow{4}{*}{$\begin{array}{l}\text { Bhattacherjee } \\
\quad[2001 \mathrm{~b}]\end{array}$} \\
\hline $\mathrm{I} 2$ & $\begin{array}{l}\text { I get rewarded for my continued shopping on the Internet (i.e. } \\
\text { free gifts, free coupons, points). }\end{array}$ & \\
\hline $\mathrm{I} 3$ & $\begin{array}{l}\text { Internet shopping generally does not give me any incentives for } \\
\text { me to continue shopping on it. }\end{array}$ & \\
\hline I4 & I get discounts to continue shopping on the Internet. & \\
\hline \multicolumn{3}{|c|}{ Customer loyalty } \\
\hline L1 & I would recommend Internet shopping to others. & Gefen [2002], \\
\hline L2 & I would encourage others to purchase through the Internet. & Homburg and \\
\hline L3 & $\begin{array}{l}\text { I would consider Internet shopping as my first choice when I } \\
\text { want to buy a product. }\end{array}$ & $\begin{array}{l}\text { Giering [2001], } \\
\text { Jones and }\end{array}$ \\
\hline L4 & I am inclined to shop more via the Internet. & Sasser [1995] \\
\hline
\end{tabular}

